\title{
Tolerance of Ambiguity: Negotiating Religion and Sustaining the Lingsar Festival and Its Performing Arts in Lombok, Indonesia
}

\author{
David Harnish
}

check for updates

Citation: Harnish, David. 2021.

Tolerance of Ambiguity: Negotiating Religion and Sustaining the Lingsar Festival and Its Performing Arts in Lombok, Indonesia. Religions 12: 626 https://doi.org/10.3390/rel12080626

Academic Editor: Heather

MacLachlan

Received: 18 June 2021

Accepted: 30 July 2021

Published: 10 August 2021

Publisher's Note: MDPI stays neutral with regard to jurisdictional claims in published maps and institutional affiliations.

Copyright: (C) 2021 by the author. Licensee MDPI, Basel, Switzerland. This article is an open access article distributed under the terms and conditions of the Creative Commons Attribution (CC BY) license (https:// creativecommons.org/licenses/by/ $4.0 /)$.
Music Department, University of San Diego, San Diego, CA 92110, USA; dharnish@sandiego.edu

\begin{abstract}
Multiple forces vie to control the narratives of the Lingsar festival, a major annual event initiated about 350 years ago that uniquely brings together the indigenous Muslim Sasak and the migrant Hindu Balinese on Lombok, an island east of Bali in Indonesia. This attention to the festival is not surprising because governments, political and religious figures, commercial interests, and tourist industries compete to define and benefit from such events worldwide. Since 1983, I have noticed a variety of changes in religious beliefs, ritual personnel and protocol, interreligious relationships, sociocultural identities, founding narratives, and performing arts over time. Once, this festival featured beliefs and performing arts that were localized, neither truly Hindu nor Islamic, and ingrained into the natural, ancestralized environment. However, the festival had to Islamize and Sasakize (that is, become more Sasak) to retain relevance among the Sasak, and had to Hinduize and Balinize to remain relevant among the Balinese. Despite these changes and increasing pressures from reformist organizations, the festival continues; in fact, it has grown in popularity and, by 2019, attracted up to 50,000 people. A tolerance of ambiguity-allowing for changing and contradictory artistic narratives, multiple ritual positions and interpretations, new positionings of interreligious relationships, and deviation from public rhetoric - has been crucial to maintain the Lingsar festival into the 21st century.
\end{abstract}

Keywords: Sasak; Balinese; Lingsar temple; festival; gamelan; music and dance; cultural politics; religious reformism; Islam and Hinduism; change and identity; Lombok

\section{Introduction}

Multiple forces vie to control the narratives of the Lingsar festival, a major annual event initiated about 350 years ago that uniquely brings together the indigenous Muslim Sasak and the migrant Hindu Balinese on Lombok, an island east of Bali in Indonesia. Whichever force commands the narratives benefits politically and both parties have vied for domination-often through the performing arts-even while cooperating intimately with the other group. Since 1983, many leaders and performers at Lingsar have died, and replacements, living in more contemporary times and experiencing new political and religio-cultural worlds, have injected both subtle and not-so-subtle changes in the festival. Despite these new elements and increasing frictions, many assert that traditions at the festival are "tetap sama" ("remain the same", see Harnish 2005). These changes, while expressing new narratives (or perhaps because they are expressing new narratives), have boosted the festival's recognition and popularity locally and nationally. The festival and its execution are now quests for identities, illustrating and reshaping Lombok's histories while reflecting the evolving interreligious relationships.

Change has probably been interwoven into the life of the festival since inception. Major festivals define a culture's identity; as social, political, religious, and/or generational changes are experienced, the underpinning narratives-expressed via performing arts, storytelling, protocol and rites-must adapt for the event to remain relevant. The unique phenomenon of two ethnoreligious groups sharing a festival introduces issues of competing 
identity trajectories and narrative control. Complicating this relationship, the Balinese are the former occupying force; Balinese rajas controlled Lombok for 200 years before their defeat by Dutch forces and it was Sasak leaders who invited Dutch intervention in 1893-94 that led to the Balinese defeat. Lingsar and its festival helped legitimize Balinese rule, and its meanings necessarily transformed throughout the colonial and independence periods of the 20th century and again into the 21st century. There is a lot at stake in the event. Historically, Lingsar-and its sacred water springs and festival-has centralized divine powers and fertility, legitimized rule, harmonized ethnicities, and irrigated vast rice fields. Today, it reconnects Sasak with their imagined history and expresses contemporary socioreligious identity while it reconfirms local Balinese as peoples of both Lombok and Bali as it articulates modern religiosity. ${ }^{1}$ As narrative expressions of respective stances, the performing arts of both groups had to be adjusted. Both groups also further embraced their respective religions, Islam and Hinduism, and ethnic identities, "Sasak" and "Balinese". These adjustments, too, were necessary for sustaining the festival.

This article explores these festival transformations and parallel religious identities as emergent 21st-century sociopolitical constructions. Since the early 20th century, the local Balinese gradually became the "others", a disempowered religious minority; ${ }^{2}$ their previous status as occupiers contributed to this alienation. Meanwhile, the Sasak narrative of the founding and meaning of the festival has dominated and now frames broader respective ethnic positions on Lombok. Occasionally, an event like this festival takes on new or greater significance as it reshapes to meet the challenges of rapid social change resulting from a mélange of global, national, and local forces. These forces destabilize cultural identity and major events, then revise or restate and then articulate that identity for the benefit of the participating community. This point explains the greater attention and larger festival numbers in the 21st century. A tolerance of ambiguity-allowing for changing and contradictory artistic narratives, a multiplicity of ritual positions and interpretations, and deviation from public rhetoric - has been crucial to maintain the Lingsar festival, the participating communities, and interreligious relationships into the 21st century, and likely also contributes to the rising numbers.

\section{Transitions}

Sasak and Balinese parties have distinct narratives of the temple's founding: Balinese hold that Balinese ancestors discovered Lingsar and Sasak believe that a Sasak or Javanese Muslim evangelist founded the site; the former highlights royal and righteous ancestors connected to divine powers (not Hindu deities), while the latter intersects Islam with "Java" (a source of Islam and righteousness) and divine ancestors. During the period of complete Balinese occupation-roughly $1738-1894^{3}$ —and well into the 20th century, Balinese authorities probably controlled the festival narrative, denying Sasak counterparts a voice. This unequal partnership, which mostly continued after Dutch colonization, transformed following Indonesian independence (1945) and more dramatically after the 1960s. Sasak narratives then seem to have become more public.

Most oral accounts suggest that Lingsar was founded in the early-to-mid 17th century. The temple walls of one of the nearby structures, Pura Ulon, indicate 1643 as the year of consecration, though dates given locally are varied and in dispute. ${ }^{4}$ Hauser-Schäublin (2003, p. 155) confirms that the sources of irrigation water were often the center of Balinese royal power; the central raja controlled this water, which in turn legitimized his reign. The principal Balinese rajas of Lombok had at least equal governance power to those of Bali (see van der Kraan 1980) and the Lingsar temple was the central water temple for West Lombok, the location of Balinese palaces. The temple, its festivals, rainwater and irrigation waters from the springs were consequently equated with royal power (see Gerdin 1982). The rajas' legitimacy may well have stemmed from overseeing the temple and waters-shared between Balinese and Sasak irrigation associations (subak) —and the successful completion of the festival. 
Several events disturbed Balinese hegemony on Lombok. Using Islam as a rallying point in the 19th century, many Sasak resisted taxation, conscription, and corvée labor, and "religion" then became a major demarcation. In 1894, Dutch forces defeated the Balinese, terminated Balinese rule, and colonized Lombok. Interlocuters claimed that festival rites and arts continued and that the Dutch recognized the festival's importance and contributed to its production during the colonial period. When Indonesia declared independence in 1945 and the Indonesian government took shape in the 1950s, a number of sociopolitical changes were initiated. Lombok was grouped with Bali in a province until 1958, when Lombok and Sumbawa (neighbor island to the east) became the Nusa Tenggara Barat (NTB) province and Bali became its own province.

Sociopolitical issues intensified locally and nationally in the 1960s. In response to a supposed communist coup attempt in the capitol of Jakarta in 1965, somewhere between 500,000-two million communists and sympathizers were slaughtered throughout the country via military and vigilante gangs into 1966 (Harnish and Rasmussen 2011, p. 25). Cribb (1990, p. 25) suggests that up to 50,000 people on Lombok died. While local Indonesian Chinese bore the brunt of this terror, some traditionalist Sasak communities-including those around Lingsar-were also targeted because their beliefs were held to be "unacceptable" (Muller 1991, p. 54). This was a pivotal moment in local history.

The local Balinese ("Lombok Balinese") have long been considered Hindus who practice a legitimate global religion (agama), but many indigenous Sasak, particularly in rural areas neighboring sacred sites like Lingsar, have often been accused of merely following adat (localized practices and customs) rather than Islam. These nominal Muslims, who follow few Islamic tenets, have been called "Wetu Telu" (Three Times). They maintained earlier beliefs in the divine ancestors and landscape and constituted the Sasak participants at Lingsar for hundreds of years. During the 20th century, Muslim reformers worked to convert Wetu Telu, sometimes violently, to normative Islam; the 1960s' violence was an extension of earlier intimidations. ${ }^{5}$ Following the slaughter, Wetu Telu culture contracted and many families quickly embraced normative Islam and began following the Muslim clerics called tuan guru-who reportedly supported the violence-for their own protection. This transition added scrutiny on Sasak participation at Lingsar and led to changes and interventions by the 1980s. Today, adat practices are more acceptable to tuan guru and the government than in the 20th century, when these practices were seen as backward, impure, and heretical. Meanwhile, the majority of Sasak around Lingsar have become practicing Muslims who also retain many adat customs.

Lingsar is unique for accommodating two ethnoreligious groups and contesting narratives. While some narrative changes reflected the transition to Dutch colonization, others were stimulated by the violence and interventions of the later 20th century. Each party, since at least the 1980s, claimed that it had a pact with divine forces and founded the site exclusively, and that the other group arrived later. This polar stance is understandable. The Lingsar site and its festival compel a desire to claim control and define identity. Whichever group commands the narrative is the superior party, while the other group is less politically and spiritually potent.

Balinese scribes occasionally wrote the Balinese narrative onto lontar palm leaves and the story outline appeared in a 1930s' government report, ${ }^{6}$ while the Sasak narrative seems to have been restricted to Sasak priests and nearby communities into the 1970s. It was popularized (and perhaps revised) in the early 1980s after the provincial Education and Culture Department conducted a project on Lingsar. The government authors of the resulting book and documentary video presented the Sasak positions and prioritized the province and its majority, indigenous people. The project coincided with efforts to increase domestic and foreign tourism and resources from the national government. Though the 1970s were a tense period when traditionalist culture and performing arts were publicly renounced, the Education and Culture project initiated around 1980 presented an opportunity to Sasak leaders. The published narrative (in Proyek Inventarisasi dan Dokumentasi Kebudayaan 1984) asserted the saintly Islamic founding of the site, the divine 
origins-in conjunction with the saint and Allah—of the water springs, and the sacrifice of the saint to preserve fertility of the area and establish the festival's rites (see Harnish 2006). In response, Balinese attempted to discount this narrative but they had little media access to promote their own story. The Sasak narrative penetrated government and media offices, and soon domestic and foreign scholars were citing it as fact as the festival became widely known.

Sasak culture and the people themselves have undergone so-called Islamization and even traditionalists such as those around Lingsar have gradually reformed their religious practice. Islamization marks a slow progression of long duration as normative Islam expands influence on regional culture and society, including on the personal lives of its members (Noorduyn 1987, p. 313). It is sometimes posited as consisting of two phases: first, the coming of Islam and its final acceptance and, second, the long struggle, still ongoing in places like Lombok, for its complete implementation (see Pelras 1993, p. 134). Islamization is a process of cultural change, based on local issues and agents on the ground, that often develops tensions between histories of adat and the demands of Islam and Muslim clerics (Noorduyn 1987, p. 313). Similar processes have occurred in Java and other islands of Indonesia. Sumarsam (2011), for instance, suggests that arts mysticism and Hindu-Buddhism were progressively augmented or replaced with Islam via Sufism in Javanese courts, and Simuh (1999, p. 14) asserts that for Javanese heritage to be retained, it had to Islamize. I believe that the Sasak culture around Lingsar also had to Islamize for participation to continue. This movement parallels the development of a new local field, Sasakologi, which involves academic and cultural study of Sasak practice and history. It is for these reasons that leaders have amplified Sufic/Islamic elements and asserted domain over Lingsar as "Sasak".

A massive economic recession and a series of student protests led to the resignation of the autocratic Indonesian president, Suharto, in 1997. ${ }^{7}$ Within a few years came democracy and provincial autonomy, which reconfigured government budgeting and led to a power vacuum that was filled by political Islam. On Lombok, tuan guru formed militias to provide security, intimidate minorities (including Balinese), and restrict cultural expression; in 2000, militias attacked churches and Chinese-owned businesses in response to Christian-Muslim violence in the Maluku Islands. Balinese then formed their own militias and I saw both Sasak and Balinese organizations securing Lingsar during the 2001 festival. The continuing push toward Islamization, assisted by the advent of social media around 2000, led to the election of a reformist clergyman, Tuan Guru Haji Bajang M. Zainul Majdi, as governor in 2008. Since 1988, the provincial governor has appeared at Lingsar to speak to participants, discuss religious pluralism, and then open the central Perang Topat (War of the Rice Squares) event. Governor Bajang never visited during his 10 years in office, demonstrating his disdain for traditionalist culture; instead, his Vice President (the late H. Muhammad Amin) represented the provincial office. In the meantime, the festival unceasingly popularized and other government offices-especially Education and Culture, and Tourism-began to play larger roles in promotion, protection, and definition of what it was and why it was held.

\section{New Ceremonies and Stances}

The Lingsar temple proper (Pura Lingsar) consists of two primary courtyards, the gadoh (an exclusive Balinese space) and kemaliq (a shared space overseen by Sasak). At the end of the 1980s, local Sasak officials challenged the denotation of the temple as "Pura Lingsar" and erected a sign that announced "Pura Lingsar dan [and] Kemaliq". The sign crafted a cognitive distinction between the courtyards and specified the kemaliq's independence from Pura Lingsar, conflated as Sasak independence from Balinese. The two courtyards and respective parties have grown much more distant since that time.

Perang Topat, one of the major rites, features Sasak and Balinese participants pelting each other with topat (or ketupat) rice squares for about $20 \mathrm{~min}$ at the end of the second and main day of the five-day festival. For farmers, this activates the rice squares as 
fertility charms; for officials, rice squares replace potential weapons in a war to harmonize relationships. As mentioned, the governor or vice-governor has given a speech exalting tolerance and then thrown out the first topat at every festival since 1988. The Balinese have opted to remain in the gadoh or kemaliq to conduct rites during this period, while the Sasak and government officials have created a formal ceremony connected to the governor's speech that presents Sasak dances and musics in folkloric performance. Though they laud the uniting of different religious groups (via Perang Topat) as enshrined in the nation's founding principles, the ceremony speakers report the Sasak narrative to the hundreds of invited guests. Journalists and scholars have focused on this formal ceremony for their coverage. Not surprisingly, they extol the Sasak founding of Lingsar. Media reports tend to be restricted to Perang Topat and ignore other events during the festival.

Sasak leaders initiated a public Sufic ritual called Haul, an annual Islamic ritual commemorating the death of an eminent figure, such as a saint, shortly after $1990 .^{8}$ This celebration fit perfectly with the Sasak legend at Lingsar: a saint with honored lineage who establishes a sacred site, creates water springs for irrigating rice fields, spreads Islam, and sacrifices himself to preserve both fertility and his essence at the site. The Haul rite is held a few days before each festival. Officials from the Ministry of Religion are invited as are those from other government branches, the military, military police, and respected local and national guests; a feast is included. Sasak leaders suggest that the Haul ritual has been going on for centuries, and conversations with attendees in the 21st century confirm this notion. The rite strengthens the Sasak narrative of Lingsar. It is part of a strategy, in my opinion, for the further control and Islamization of the site and festival. Islamization in contemporary Lombok fosters greater legitimation, increased attention (and resources), and even protection for some of the adat practices continuing at the festival.

During transitional years-roughly 1988-2017-changes were underway within festival protocol and performing arts, and the Sasak became increasingly empowered through connections with the government, education, media, and tourism. Reform movements within Islam and Hinduism (locally, nationally, and globally) continued to inspire Sasak and Balinese to become more "Muslim" and more "Hindu" as both reassessed their positions. This was transformative because, in my opinion, the festival became more "Islamic" and "Hindu" only in the 20th century, despite the contention by both parties that it was one of the other (or both) from the outset.

Though elements of these religions had a place in earlier centuries-Sufic features for Sasak (e.g., the kemaliq representing a shrine to a saint) and Hindu notions of royal power and holy water for Balinese (Sasak share these conceptions) - the original practices and narratives were couched in adat. During the 17th-century of the temple's founding, Islam was likely only practiced in parts of East Lombok, ${ }^{9}$ and the word "Hindu" was probably unknown among Balinese commoners. None of the rites at Lingsar in 1983, the first year I attended, related to normative practice for either religion, though new interpretations, ceremonies, and rhetoric have since been implanted to construct the festival both more "religious" and "cultural". Developments within the performing arts reflect these changes. Lombok Balinese performing arts, for instance, transitioned to meet existential challenges to their identities and acknowledgement within the festival, while Sasak performing arts transformed from more ritually prescribed to both more presentational and more distinctly "Sasak".

\section{Performing Arts Transitions}

Sasak and Balinese leaders, participants, and performing arts at Lingsar were subject to provincial and external pressures from national movements and reformist organizations. Among Muslims on Lombok, Nahdlatul Wathan (NW; locally developed in 1953 and based upon the national Nahdlatul Ulama) and tuan guru have been the primary drivers of reformism; among the Balinese, the Parisada Hindu Dharma Indonesia (PHDI) has fostered modernizing and unifying Hindu arts and practices for Balinese on Lombok and Bali (and elsewhere). Formerly, the performing arts at Lingsar embodied and put into 
action the narratives that powered the festival and gave it meaning. As such, they were context-specific and related to the time, place, and position in the festival frame. Music or dance performances also constituted rites on their own and several of these invited deities to descend into the space or otherwise created "bridges" to the ancestors (Harnish 2006). Most music-making involved gamelans. Primary Balinese gamelans included the ceremonial gong kuna and multiple processional gamelans called gong gilak and balaganjur. ${ }^{10}$ The performance of gamelan gong kuna — consisting of slab metallophones, gong chimes, gongs, and drums-on the morning of the first festival day was the opening ritual and called deity and human worlds to the temple. This gamelan was normally converted into a modern gong kebyar (replacing the metallophones) to accompany ritual dances within the Balinese courtyard, gadoh. Balinese dances included a masked dance theatre (topéng) featuring a few dancers abstractly dramatizing the Balinese myth, and a men's offering dance, Canang Sari, both held on the second, main day of the festival.

In the 1990s, a kidung a cappella club, largely featuring women singing praise songs to deities, was added to every festival and became a new "tradition". While it was widespread on Bali, kidung was rare on Lombok. Greater communications in the 1990s among the diaspora on Lombok yielded standardization of Hindu Balinese ritual performance, such as including kidung singing clubs at temple festivals. Balinese officials decided that the kidung club should be positioned within the kemaliq courtyard shared with the Sasak to further Hinduize that space and make Balinese feel "more at home" there. I believe this was as much a political step as a religious one, since it represented a statement of Hinduism within the courtyard acknowledged by Sasak as a shrine to the Muslim saint; the addition also demonstrated increasing religiosity (see Figure 1).

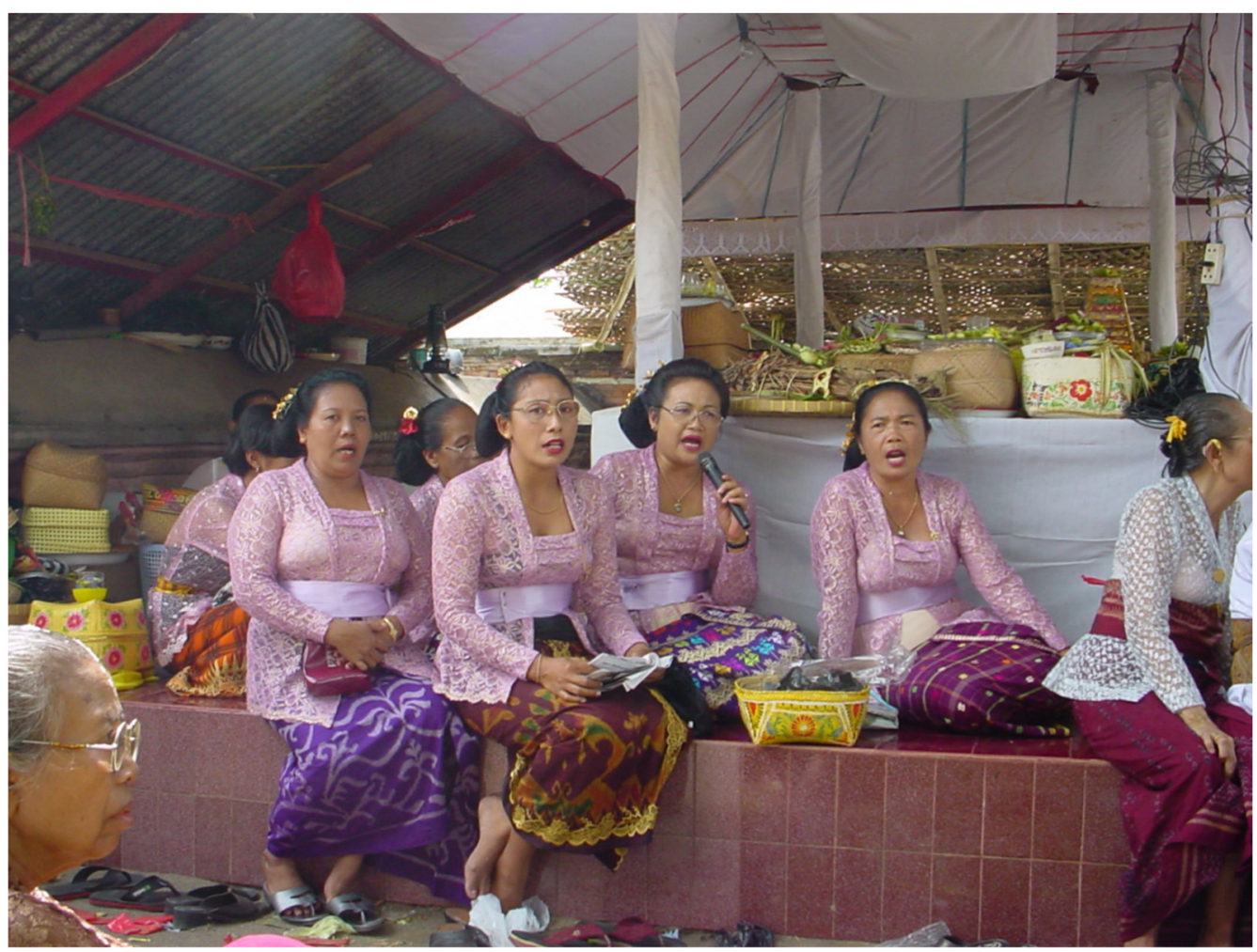

Figure 1. Balinese women kidung singers in the kemaliq, Lingsar, 2001. Photo by author.

The topéng performance disappeared in the 1990s and has never been held again; the explanation I received was that the program was too full. One new dance, however, Rejang Déwa was instead added to the program. Featuring eight women dressed in yellow and white wearing distinctive head-dresses, Rejang Déwa was a modern, ritual dance with set choreography and a favorite of Hindu reformers that the PHDI imposed upon many 
temple programs. Rejang Déwa and kidung were outcomes of a reformist movement built upon unifying Balinese practice.

Another change was the modification of the Canang Sari dance. Until the 1990s, the dance featured five males who improvised and 'danced' special offerings into the gadoh and handed them to priests, who placed the elaborate offerings into specific altars. The changes sanctioned 20 or more men, women, and children to participate, and the offerings simplified. One priest said in response that he was disappointed and that the dance and offerings were no longer meaningful; on the other hand, one young man suggested that allowing women and children to dance was liberating and in accord with the new democracy within Indonesia, as the country transitioned from authoritarian and centralized to democratic and decentralized. The modifications of Canang Sari and the additions of kidung and Rejang Déwa at the same time newly provided women the opportunity to perform. Previously, Balinese women did not dance at the festival. In keeping up with changes on Bali, officials instituted another new offering dance in the mid-2010s, Rejang Renteng, featuring elder women (Harnish 2021). While in the 1980s the performance program at Lingsar was distinct to the local Balinese and traditions there, now it is indistinguishable from most programs at temple festivals on Bali. Correspondingly, the local Balinese have become less "local" and more "Balinese", and the arts have become less "local" and more "Hindu Balinese" (see Table 1).

Table 1. Changes in Performing Arts at Lingsar over Three Decades.

\begin{tabular}{ll}
\hline \multicolumn{1}{c}{ Performing Arts in the 1980s } \\
\hline Sasak & Musics: Gamelan tambur/baris; preret; balaganjur \\
\hline & Dances: Baris Lingsar / Batek Baris \\
\hline Balinese & Musics: Gamelan gong kuna; gong gilak; balaganjur \\
\hline & Dances: Topéng; Canang Sari (5 dancers) \\
\hline \multicolumn{1}{c}{ Performing Arts in 2017 } \\
\hline Sasak & Musics: Gamelan tambur/baris; multiple gendang beleq; tawaq tawaq \\
\hline Balinese & Dances: Baris Lingsar/Batek Baris \\
\hline & Musics: Gamelan gong kuna; “balaganjur”; balaganjur; kidung \\
\hline & Dances: Canang Sari (ca. 20 dancers); Rejang Déwa; Rejang Renténg \\
\hline
\end{tabular}

Sasak performing arts were, of course, also subject to change. In the 1980s gamelans, dances, and preret double-reed oboe were featured. The gamelan tambur, the eldest and most sacred ensemble consisting only of a gong and drum, led processions. The gamelan baris grew out of gamelan tambur, added a few other instruments such as flute and fiddle, and accompanied the dances. The ritual dances were Baris Lingsar (nine men dressed like Dutch soldiers) and Batek Baris (the men plus the batek characters of cross-dressed women). Two preret players were charged with musically accompanying the creation and processing of the main festival offerings, the kebon odeq, and playing for other rites. The preret's music was the sound symbolism of kebon odeq and a Wetu Telu index of "ritual".

In the 1990s, the preret players were no longer invited to the festival. I interpreted this neglect to the Wetu Telu associations of the preret and to the efforts to Islamize the festival and extricate participating Sasak from discredited traditionalist beliefs. The preret no longer represented the emerging identity preferred by Sasak officials. Another ensemble, gendang beleq, was then added to the Sasak program. This ensemble had been modernized and secularized in the 1980s; it features cymbals, gongs, gong chimes, flute, and huge drums (see Figure 2). At Lingsar, multiple gendang beleq clubs perform in the processions and others perform choreographed shows outside-and occasionally inside- the temple. Gendang beleq are among the loudest ensembles on Lombok; multiple ensembles playing puts a powerful sonic stamp on the festival as Sasak. Their ascendance at Lingsar symbolizes a 
change from ritual function in the arts to presentational showmanship, and a more cultural and secular Sasak presence. Thus, as preret is absent and gendang beleq are added, links to earlier arts are weakened while more commoditized Sasak arts are highlighted. The formal ceremony outside the temple features the new Sasak ritual arts that are folkorized as entertainment and serve as spectacles to educate a non-participating and often a nonLombok audience.

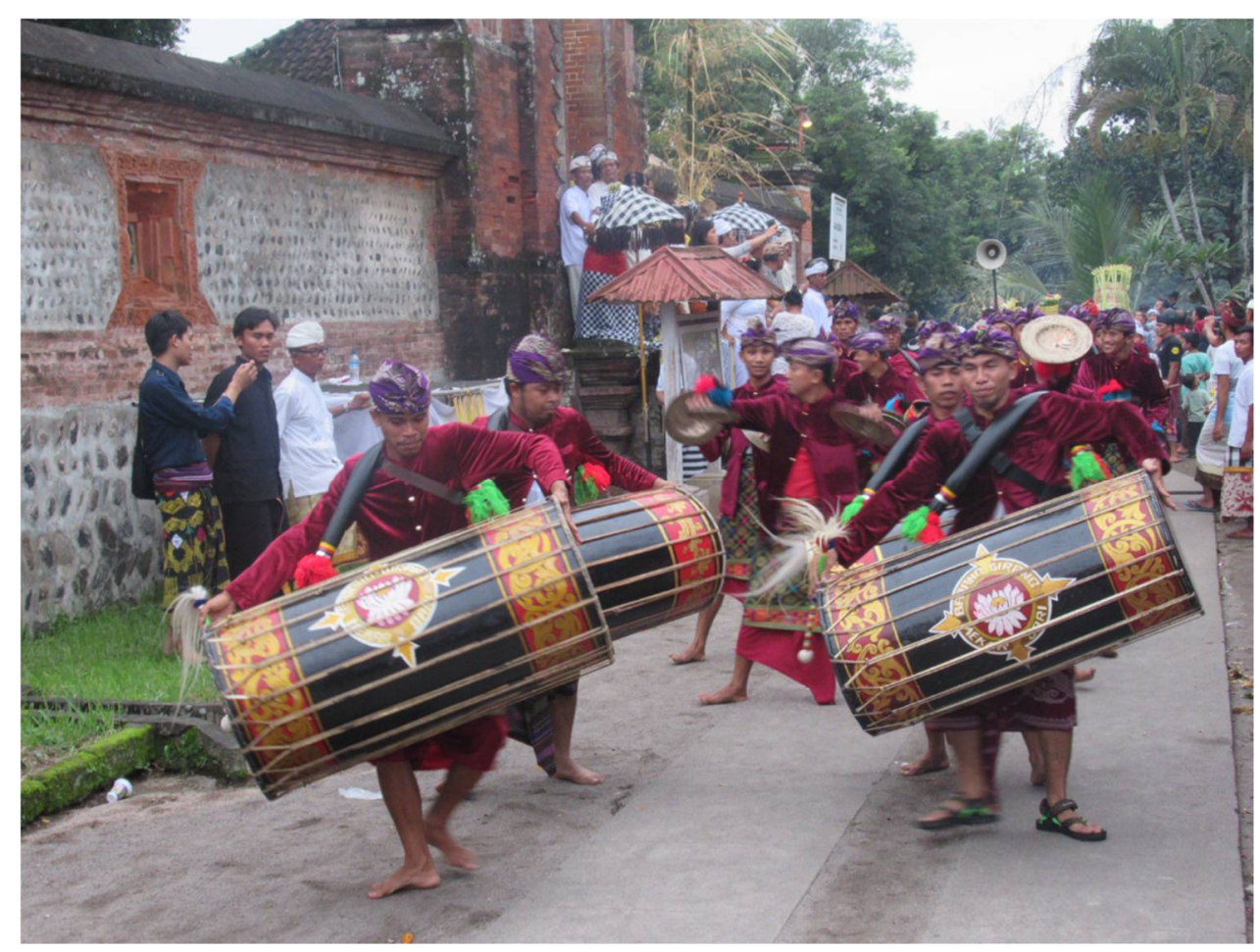

Figure 2. A circumambulating Sasak gendang beleq troupe processes passed the Balinese gadoh, Lingar, 2017. Photo by author.

One other change was the switch from a gamelan balaganjur for processions to a different processional gamelan, tawaq tawaq, which was also incorporated into the formal ceremony. Some say that tawaq tawaq was a part of the festival processions before 1980 and thus was "traditional", implying that the ensemble has been reintroduced. Gamelan tawaq tawaq did not appear during the festivals I attended from 1983-2001; I first noticed it in the 2009 festival. Its appearance brings another icon of Sasak culture into the mix (see Table 1). ${ }^{11}$ Despite increasing Islamization, Sasak participation needs to be cultural rather than Islamic because a kemaliq, though a shrine where a saint introduced Islam, is not a mosque, and this effort decouples Lingsar (a Wetu Telu and Hindu Balinese site) from religion. On the other hand, the Haul rite further Islamizes the festival; these changes among the Sasak transform participation from a local observance of the deified landscape for increased fertility to a celebration more Islamic and more "Sasak", while also asserting that the festival is fundamentally "Sasak". These developments, along with recent evolutions in the Sasak myth that further cement the founding of Lingsar as both "Islamic" and "Sasak" (see Harnish 2006, 2021), demonstrate that changes can be uncritically absorbed and reconstituted as "tradition" within a generation. They also reveal states of ambivalence.

\section{Ambiguity and Its Tolerance}

Matthias Junge (2008) asserts that ambivalence can arise within people experiencing their presence in times of rapid social change during transformations of a social order. The recent history of Lombok is a case study of disruption, going through Balinese, Dutch and Japanese occupations (the latter during World War II), Javanese dominance, civil violence, 
political Islam and sectarian violence, transitions from centralized to decentralized and from authoritarianism to democracy, and the advents of provincial autonomy and militias. Sociopolitical turbulence has become normal, creating structures of ambivalence. Identities and belonging in periods of social change are in fluctuation, hope and fear become interchangeable, and new cultural interpretations are not only possible but necessary. Campbell (2019) notes the tensions, paradoxes, and ambiguities involved in cultural representations like festivals and reenactments, and Gottowik (2019), addressing Lingsar directly, cites commonalities and differences and the recognition of contradictory interpretations of ritual acts by Sasak and Balinese as essential features of every symbolization exuding a tolerance of ambivalence.

Ambivalence often addresses tensions and negotiations as processes to position oneself in a given context. Sasak leaders seem to have negotiated from an ambivalent station how to incorporate the residuum of their past into circumstances in the present. I can recall when the Sasak were criticized for, or even forbidden from, participating in the festival. The "past" among Sasak leaders referred mostly to Wetu Telu culture, pre-Islamic beliefs, and dominance by the Balinese-all things that they wanted eradicated. Leaders appropriated the power to define relevant elements of the past and revive and shape those elements, taking structures of ambivalence and crafting articulated Sasak identities both traditional and Islamic. This agency led to the institutionalization of the Haul ritual, the halting of preret performance, the addition of gendang beleq, and the Muslim hero narratives, together constituting a continuum of Islamization.

Balinese leaders have been ambivalent about their positions on Lombok vis à vis their ancestors' origins on Bali. For centuries in a superior position, they became a religious minority and saw both their advantages and control over Lingsar disappear. They are both Balinese and citizens of Lombok and form their identities from this ambivalence. Like the movement to Islamize and Sasakize the festival, Balinese leaders felt that the festival had to become more Hindu and more Balinese. Then came the installation of a kidung choir, the incorporation of the Rejang Déwa dance-a badge of modern Balineseness and a favorite of PHDI - the democratizing of the Canang Sari dance, and then the addition of another new sacred dance promoting modern Balinese Hinduism, Rejang Renténg. In response to the personal discomfort caused by ambivalence, Lombok Balinese authorities have chosen to take on modern identities generated from Bali-both "Hindu" and "ethnic" - while attempting to homogenize performance programs at Lingsar and other festivals.

\section{Concluding Interpretations}

Sasak and Balinese both need the Lingsar festival, but their needs differ and have grown more distinct. The world was different when Balinese controlled Lombok, royals underwrote the festival, and the Balinese organization worked with Sasak to create harmony and fertility, and ultimately to legitimize the rajas. Sasak locals and farmers, dependent upon rice, rainwater, and continuing connections with the ancestralized landscape, endured and normalized a very unequal relationship. The Dutch victory over the Balinese did not seem to affect this relationship or the festival narrative. The dramatic political shifts later in the 20th century-occupation during World War II by Japanese forces, the advent of the Indonesian nation state-begin to challenge established understandings, though Islamization and the post-1960s violence quickly advanced new possibilities for Sasak leaders. These opportunities come to fruition with the Education and Culture project beginning around 1980 and the assertion of the Sasak myth and ownership over the festival, directly undermining Balinese authority, which continually waned to the end of the 20th century and even further into this century.

The festival attracted more attention in the 2010s due to increased media coverage and the growing status of the kemaliq and Perang Topat as "Sasak". During this decade, a number of Sasak groups formed to study and promote adat practices and Sasak Islam. Toward the end of that decade came a new discipline at universities and among intellectuals, Sasakologi, focused on Sasak history, culture and religion. These intersecting movements 
constituted a rejection of both the Arabization of Islamic practice (earlier pressed by some tuan guru) and of Balinese influence on Sasak culture, long assumed by earlier foreign and Indonesian scholars. Since many remnants of earlier Sasak culture-for instance, Wetu Telu mosques and shrines-were destroyed in the 20th-century attempt to eradicate impure practice, it is not surprising that Lingsar became an increased object of fascination for its Sasak heroes and sacred sites, arts, and rituals. The interreligious harmony that underpinned the festival (especially Perang Topat) was publicly downplayed to proclaim that this is a Sasak event that Balinese are invited to join. The festival's earlier functions have further modified. The government erected water pumps nearby so that farmers and collectives are not dependent upon the festival to regulate the rice cycle, thus undermining the status of uniting divine powers (conflated as Sasak/female and Balinese/male; see Harnish 2001) to increase rainwater and fertility. Though interreligious harmony is still experienced by many participants-and cooperation is required for several rites-the Perang Topat, in particular, could become a celebration of Sasak adat and accomplishment, discarding previous understandings and Balinese contributions.

Lingsar is the central point of interreligious and interethnic relationships on Lombok; the festival and its myriad performing arts have been a barometer for measuring change in these relationships. What I first witnessed at the Lingsar festival in 1983 expressed a Sasakness rather than an Islamness and a local Balineseness rather than a Hindu Balineseness. That era is over. Sasak and Balinese have worked over decades to Islamize and Hinduize the festival; this effort was necessary not only for the event's continued relevance as Lombok modernized and experienced religious reform but also for sustained interethnic relationships and the establishment of national and socioreligious identities. The event and its participants had to modernize. However, on Lombok, where Sasak are the vast majority and Islam is the majority religion, Lingsar and everything it symbolizes have become a foundation of indigenous Sasak identity, and their participation has ambiguously become both more Islamic and secular.

It is remarkable that this festival, despite upheavals and tensions, has been maintained for over 350 years, and it constructs a breathtakingly unique social community for both Lombok, Indonesia, and the world. A tolerance of ambiguity, between and within each camp and realized in the evolving performing arts, allows the event to continue annually. This ambiguity tolerance allows Sasak to be both properly Muslim, participate with Balinese, and engage in Perang Topat, and allows Balinese to be both properly Hindu, united with the greater Balinese community, and integrated citizens of Lombok.

Funding: The research informing this article was conducted over 34 years. Some fieldwork projects received funding (IIE Fulbright-Hayes, DOE Fulbright Hayes) and the 2017 project was funded by a University of San Diego Faculty Research Grant.

Institutional Review Board Statement: The study was conducted according to the guidelines of the Declaration of Helsinki, and approved by the Institutional Review Board of University of San Diego (2014-11-086).

Informed Consent Statement: Informed consent was obtained from all subjects involved in the study. The present work does not quote those subjects.

Conflicts of Interest: The author declares no conflict of interest.

\section{Notes}

1 My previous findings $(2005,2006)$ concluded that the main goal was to achieve interreligious harmony, which leads to spiritual balance and fertility. Research in 2017 revealed that this harmony has declined and to some extent is no longer the primary goal.

2 Sasak are by far the majority population, constituting over 85\% of Lombok's 3.8 million inhabitants. Depending on the source, Balinese number between 160,000-445,000 and reside almost entirely in West Lombok. They are the majority at the festival.

3 Balinese controlled western Lombok, including Lingsar, by 1677 (Kingsley 2012, p. 96). Balinese influence is clear there by at least 1603 (Hägerdal 2001, p. 18) and likely a century earlier.

4 Various dates given are 1759, 1714, and 1710. Balinese consider Pura Ulon to be the elder temple but the Sasak assert it is a newer temple; it could have been constructed around 1643 and Pura Lingsar itself in the early 18th century. Sasak believe that their 
shrine predates either Balinese pura (temple). The oral histories I collected in the 1980s suggested mid-to-late 1800s for Pura Lingsar. A booklet published by the Balinese temple organization (Krama Pura) states that Pura Ulon was built in 1658 and Pura Lingsar in 1753.

5 In tandem with this pressure, a district leader forbid the Sasak pemangku (priest) from officiating at Lingsar in 1968. He claimed that the festival was Hindu and that, as Muslims, Sasak could not participate. After requests from Balinese authorities, the leader relented and the pemangku could officiate but only under the rationale of "culture" (budaya). This ruling distinguishing culture from religion (agama) became the rationale for Sasak participation, though many Sasak continued previous practices.

6 The Balinese narrative has been fairly consistent over time. The basic outline is this: Nobles from East Bali are invited to Lombok to defend a threatened Sasak noble; they consult with a deity in a hill temple (Pura Bukit) and are told travel instructions; leaves transform into butterflies to guide the mission across the Lombok Strait; they arrive and are guided to Lingsar, where the local deity spouts; this deity supplies a spirit army to help defeat unjust Sasak kingdoms and the Balinese return to build the temple at Lingsar.

7 Suharto became president in 1967 following the 1960s violence, which brought down the previous president, Sukarno. Suharto's regime instituted neoliberalism, education, centralization, corruption, and religious tolerance, and squelched all resistance.

8 This ceremony did not occur in the 1980s, to my knowledge. I was first invited by the Sasak pemangku to this ritual in 1993. Alatas (2007) discusses how Haul celebrations proliferated in 20th-century Indonesia as reactions against the tide of modernity and reformism while formulating collective memory, identity for participants, and affirming the authority of descendants. The rite at Lingsar can legitimize the entire line of Sasak pemangku, who are considered descendants, as the primary authoritative figures.

9 By that time, there were Islamic kingdoms in East Lombok, notably Penjanggik and Selaparang. Islam was introduced in the east by forces from Sulawesi entering via neighboring Sumbawa. The original point of introduction is said to be Bayan in North Lombok. A saint related to the legendary wali sangha (nine saints) on Java, spread the religion, which mixed with local beliefs to shape the Wetu Telu faith.

10 These ensembles continue to appear at Lingsar. Gong gilak-a more localized term-and balaganjur have similar instrumentation; the latter on Lombok has lacked gong chimes. In the 21st century was a move to unify local terms with Bali, and people have referred to "gong gilak" as "balaganjur"; thus, some balaganur include gong chimes and the others do not.

11 Gamelan tawak tawak features cymbals connected to large tasseled lances. The former Sasak gamelan balaganjur, a style shared with Balinese (and this may be one reason why it changed), was assembled from the instrumentarium of a gamelan gong Sasak that consistently performs outside the temple.

\section{References}

Alatas, Ismail F. 2007. The Upsurge of Memory in the Case of Haul: A Problem of Islamic Historiography in Indonesia. Journal of Indonesian Islam 1: 267-79. [CrossRef]

Campbell, Corinna. 2019. Ambivalent Expressions: Productive Anxieties in Folkloric Performance. Paper presented at the 65th Society for Ethnomusicology Conference, Bloomington, Indiana, November 7-10.

Cribb, Robert. 1990. Problems in the Historiography of the Killings in Indonesia. In The Indonesian Killings of 1965-66: Studies from Java and Bali. Edited by Robert Cribb. Clayton: Centre of Southeast Asian Studies, Monash University, pp. 1-44.

Gerdin, Ingela. 1982. The Unknown Balinese: Land, Labour, and Inequality in Lombok. Goteburg: Universitatis Gothoburgensis.

Gottowik, Volker. 2019. Cooperation and Contestation at a Shared Sacred Site: The Lingsar Festival on Lombok, Indonesia. In Volume 10: Interreligious Dialogue: From Religion to Geopolitics. Edited by Giuseppe Giordan and Andrew P. Lynch. Leiden: Brill Press, pp. $49-69$.

Hägerdal, Hans. 2001. Hindu Rulers, Muslim Subjects: Lombok and Bali in the Seventeenth and Eighteenth Centuries. Thailand: Hans Hägerdal.

Harnish, David D. 2006. Bridges to the Ancestors: Music, Myth, and Cultural Politics at an Indonesian Festival. Honolulu: University of Hawai'i Press.

Harnish, David D. 2021. Change and Identity in the Music Cultures of Lombok. Leiden: Brill Press.

Harnish, David D., and Anne Rasmussen. 2011. The World of Islam in the Music of Indonesia. In Divine Inspirations: Music and Islam in Indonesia. Edited by David Harnish and Anne Rasmussen. New York: Oxford University Press, pp. 5-44.

Harnish, David. 2001. 'Like King and Queen, like Balinese and Sasak': Musical Narratives at the Lingsar Festival. Ethnologies 23: 63-87.

Harnish, David. 2005. New Lines, Shifting Identities: Interpreting Change at the Lingsar Festival in Lombok, Indonesia. Ethnomusicology 49: 1-24. [CrossRef]

Hauser-Schäublin, Brigitta. 2003. The Precolonial Balinese State Reconsidered: A Critical Evaluation of Theory Construction on the Relationship between Irrigation, the State, and Ritual. Current Anthropology 44: 153-81. [CrossRef]

Junge, Matthias. 2008. The Ambiguity of Bauman's Conception of Ambivalence. In The Sociology of Zygmunt Bauman: Challenges and Critique. Edited by Michael Hviid Jacobsen and Poul Poder. Burlington: Ashgate, pp. 41-56.

Kingsley, Jeremy. 2012. Peacemakers or Peace-breakers? Provincial Elections and Religious Leadership in Lombok, Indonesia. Indonesia 93: 53-82. [CrossRef]

Muller, Kal. 1991. Wetu Telu: Mix of Islam and Traditional Adat Practices. In East of Bali: From Lombok to Timor. Edited by Kal Muller. Berkeley: Periplus Editions, Inc., pp. 54-55. 
Noorduyn, Jacobus. 1987. Makassar and the Islamization of Bima. In Bijdragen tot de Taal-, Land-en Volkenkunde. Deel 143, $2 / 3$ Afl. Leiden: Brill Press, pp. 133-54.

Pelras, Christian. 1993. Religion, Tradition, and the Dynamics of Islamization in South Sulawesi. Indonesia 57: 312-42. [CrossRef]

Proyek Inventarisasi dan Dokumentasi Kebudayaan. 1984. Upacara Tradisional Dalam Kaitannya Dengan Peristiwa Alam dan Kepercayaan di Nusa Tenggara Barat. Mataram: Departemen Pendidikan dan Kebudayaan.

Simuh. 1999. Suluk: The Spiritual Potency of Javanese Muslims. In Indonesian Heritage: Religion and Ritual. Edited by James Fox. Singapore: Editions Didier Millet/Archipelago Press, pp. 14-15.

Sumarsam. 2011. Past and Present Issues of Islam within the Central Javanese Gamelan and Wayang Kulit. In Divine Inspirations: Music and Islam in Indonesia. Edited by David Harnish and Anne K. Rasmussen. New York: Oxford University Press, pp. 45-79.

van der Kraan, Alfons. 1980. Lombok: Conquest, Colonization and Underdevelopment, 1870-942. Singapore: Heinemann Educational Books (Asia) Ltd. 